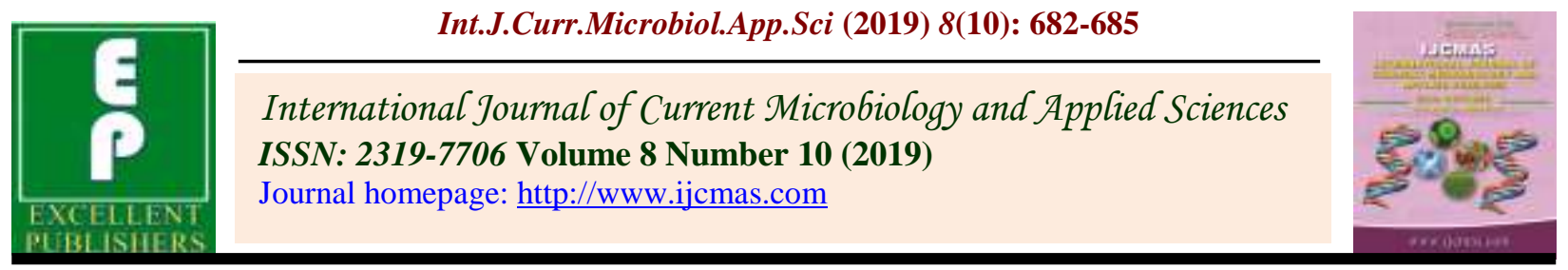

Short Communications

https://doi.org/10.20546/ijcmas.2019.810.077

\title{
Constraints Faced by Rice Growers in Adoption of Recommended Rice Cultivation Practices in Palghar District of Maharashtra, India
}

\author{
R. S. Karangami*, S. A. Dhenge, S. V. Yadav and P. G. Mehta \\ Department of Extension Education, PGI, MPKV, Rahuri (M.S.), India \\ *Corresponding author
}

\section{A B S T R A C T}

\section{Keywords}

Constraints,

Adoption,

Recommendation,

Rice growers

\section{Article Info}

Accepted:

07 September 2019

Available Online:

10 October 2019
The present study was conducted in Palghar district of Maharashtra state. Palghar district two tahsils namely Wada and Palghar selected purposively for this study on the basis of maximum area under cultivation of rice crop. From each selected tahsil of the district six villages selected for this study on the basis of maximum area under cultivation of rice crop. Total 12 villages were selected. From each selected village 10 respondents selected for the present study by random sampling method. Thus, the total 120 respondents was the sample for this study. The respondents were interviewed with the help of a specially designed schedule. The ex-post facto research design was used for the present study. The analysis of data revealed that majority of the respondents were 'middle' age, had 'secondary' education, 'marginal' area under rice cultivation, India is facing the challenges of food and fodder production to meet the demand of rising human and cattle population. In India, rice is the promising crop to acquire self sufficiency of food grain production for the population. The area, production and productivity of rice crop in Palghar district was 14980 ha., 36641 qtls, $2446 \mathrm{~kg} / \mathrm{ha}$. respectively, in the year 2014. The major constraints faced by farmers in adoption of selected agricultural technologies of rice crop were shortage of labourers, unavailability of fertilizer at proper time and lower market price of produce, respectively.

\section{Introduction}

A major need to the developing countries is to raise the standard of living of the people in general and rural in specific. In India, where agriculture occupies a dominant position in the economy of country, economic growth and progress actually depends to a large extent on the improvement of agricultural technology and adoption of agricultural innovations by the farmers. Therefore, it is necessary to change the attitude of the farmers so that they may shift from traditional to modern methods of farming. Rice (Oryza sativa L.) is one of the most important cereal grains in the world today and serves as a staple food source for more than half of the world's population (Source.www.thecropsite.com), particularly in India, China and a number of other countries in Africa and Asia. India is facing the challenges of food and fodder production to meet the demand of rising human and cattle population. One of the major causes of this 
problem is low level of adoption of improved agricultural practices by the farmers.

There are three seasons for growing rice in India viz. autumn, winter and summer. The main rice growing season in the country is 'kharif'. It is known as winter rice as per the harvesting time. The sowing time of kharif rice is June - July and it is harvested in September - October. India is an important centre of rice cultivation. The rice is cultivated on the largest areas in India. The world rice cultivated on the area of 221.61 million hectares with production of 728.07 million metric tons in the year 2013-2014. Thus, rice production; consumption and trade are concentrated in Asia. More than 90 per cent of global production is occurring in tropical and semi-tropical Asia.

In India, rice is the promising crop to acquire self sufficiency of food grain production for the population. Rice crop occupy the largest cultivated land in the country. It was cultivated on the area of 43.95 million hectares with production of 106.54 million tons in the year 2013-2014. Maharashtra rice is grown on area of about 1.56 million hectares with a production of about 2.95 million tons. (www.irri.org)

In Maharashtra State, rice is the main crop grown in the costal districts of the Konkan region mainly in the five districts namely Thane, Raigad, Ratnagiri, Sindhudurg and Palghar districts. The package of practices of rice cultivation is being recommended by DBSKKV, Dapoli since 1972. In Konkan region the area is about 0.44 million hectares with a production of about 15.10 lakh tons in the year 2013-2014 (Source: Directorate of Economics and Statistics, Department of Agriculture and cooperation, GOI 2013-2014). The area, production and productivity of rice crop in Palghar district was 14980 ha., 36641 qtls, $2446 \mathrm{~kg} / \mathrm{ha}$. respectively, in the year 2014.

\section{Materials and Methods}

From Palghar district two tahsils namely Wada and Palghar selected purposively for this study on the basis of maximum area under cultivation of rice crop. From each selected tahsil of the district six villages selected for this study on the basis of maximum area under cultivation of rice crop. Total 12 villages were selected. From each selected village 10 respondents selected for the present study by random sampling method. Thus, the total 120 respondents was the sample for this study. The data collected was processed, quantified, categorized and tabulated. The established parameters like mean, frequency, percentage, standard deviation and Chi square test were calculated.

\section{Results and Discussion}

An attempt was made in the present investigation to understand the constraints experienced by the farmers in adoption of selected agricultural technology. The constraints reported by the respondents are presented in table 1 .

The present study have seen constraints faced by farmers in rice cultivation were shortage of labour (80.00 per cent), unavailability of fertilizer at proper time (75.00 per cent), inadequate irrigation facility (48.34 per cent), lower market price of produce (70.83 per cent), high cost of inputs (69.17 per cent), high cost of machineries (68.34 per cent), lack of knowledge for making appropriate concentration of insecticide / fungicide for use (65.00 per cent), non availability of quality seeds (61.67 per cent), high cost of pesticide and fungicides (60.08 per cent), unavailability of weedicide at village (52.5 per cent), non availability of compost (46.67 per cent), and unavailability of seeds in time (39.17 per cent), could not identified pest and disease (37.50) (Table 1). 
Table.1 Constraints of adoption of rice cultivation practices by farmers

\begin{tabular}{|c|c|c|c|}
\hline \multirow{2}{*}{$\begin{array}{l}\text { Sl. } \\
\text { No }\end{array}$} & \multirow[t]{2}{*}{ Constraints } & \multicolumn{2}{|c|}{ Respondents $(\mathrm{N}=120)$} \\
\hline & & Frequency & Percentage \\
\hline 1. & Shortage of labour & 96 & 80.00 \\
\hline 2. & Unavailability of fertilizer at proper time & 90 & 75.00 \\
\hline 3. & Unavailability of seeds in desired quantity. & 87 & 72.50 \\
\hline 4. & Inadequate irrigation facility & 58 & 48.34 \\
\hline 5. & Lower market price of produce & 85 & 70.83 \\
\hline 6. & High cost of inputs & 83 & 69.17 \\
\hline 7. & High cost of machineries & 82 & 68.34 \\
\hline 8. & $\begin{array}{l}\text { Lack of knowledge for making appropriate } \\
\text { concentration of insecticide / fungicide for use. }\end{array}$ & 78 & 65.00 \\
\hline 9. & Non availability of quality seeds & 74 & 61.67 \\
\hline 10. & High cost of pesticide and fungicides & 73 & 60.08 \\
\hline 11. & Unavailability of weedicide at village & 63 & 52.5 \\
\hline 12. & Non availability of compost & 56 & 46.67 \\
\hline 13. & Unavailability of seeds in time & 47 & 39.17 \\
\hline 14. & Could not identified pest and disease & 45 & 37.50 \\
\hline
\end{tabular}

The efforts for the development of the farmer need an integrated approach. The farmer living in rural areas directly or indirectly depend upon agriculture as a source of livelihood. The rice grower cultivators in the Konkan region own marginal and small land holdings and grow rice crop which is not much remunerative. The study has categorically pointed out that high cost and unavailability of agriculture inputs in time were the most severe constraints experienced by the farmers in adoption of those practices which were of situational in nature. Thus, they may be motivated to adopt modern technology for forming groups, co-operatives. Farm scientist, extension organizations and input supply agencies may adopt suitable policies and programmes to overcome such conditions.

\section{Acknowledgement}

The authors thankful to the Department of Extension Education, College of Agriculture, Dr. Balasaheb Sawant Konkan Krishi
Vidyapeeth, Dapoli, Ratnagiri, Maharashtra for providing all the inputs and facilities to carry out this study.

\section{References}

Bhosale, U.S. (2010). Participation of rural youth in paddy farming in Anand district of Gujarat state. M. Sc. (Agri.) Thesis, AAU, Anand (Gujarat). (Unpublished).

Dhenge, S.A. (2013) Knowledge and adoption of integrated pest management practices by paddy growers M. Sc. (Agri.) Thesis, Dr. Panjabrao Deshmukh Krishi Vidyapeeth, Akola. (M.S.).

More, S. V. (2011). Factors influencing adoption of hybrid rice cultivation technology in Ratnagiri district. M.Sc. (Agri.) Thesis, Dr. Balasaheb Sawant Konkan Krishi Vidyapeeth, Dapoli (M.S.).

Pawar P. B. (2009). A study on Inter-Gender 
involvement in paddy and sugarcane crops Cultivation in Navsari Districts of Gujarat state, M.Sc. (Agri.) Thesis N.A.U., Navsari.

Telange Prajakta, (2015). Extent of adoption and causes of non-adoption of rice varieties developed by DBSKKV, Dapoli. M.Sc. (Agri.), Thesis, Dr. Balasaheb Sawant Konkan Krishi Vidyapeeth, Dapoli (M.S.).

Thakur, V. V. (2011). Influence of social values on adoption of the recommended rice cultivation practices. M.Sc. (Agri.) Thesis, Dr. Balasaheb Sawant Konkan Krishi Vidyapeeth, Dapoli (M.S.).

Wadekar, R.P. (2013). Adoption of rice cultivation practices by Warli tribal farmers from Thane district of Maharashtra. M.Sc. (Agri.) Thesis, Dr. Balasaheb Sawant Konkan Krishi Vidyapeeth, Dapoli (M.S.). www.agristat.com. www.irri.org

\section{How to cite this article:}

Karangami, R. S., S. A. Dhenge, S. V. Yadav and Mehta, P. G. 2019. Constraints Faced by Rice Growers in Adoption of Recommended Rice Cultivation Practices in Palghar District of Maharashtra, India. Int.J.Curr.Microbiol.App.Sci. 8(10): 682-685.

doi: https://doi.org/10.20546/ijcmas.2019.810.077 